\title{
ASSESSMENT OF PROPERTIES OF COARSE-ENERGY PLANTS
}

Živilè ČERNIAUSKIENĖ, Institute of Energy and Biotechnology Engineering, Faculty of Agricultural Engineering, Aleksandras Stulginskis University, Studentu str. 15, LT-53362, Kaunas distr., Lithuania, e-mail: zivile.cerniauskiene@ asu.lt (corresponding author) Egidijus ZVICEVIČIUS, Institute of Energy and Biotechnology Engineering, Faculty of Agricultural Engineering, Aleksandras Stulginskis University, Studentų str. 15, LT-53362, Kaunas distr., Lithuania, e-mail: egidijus.zvicevicius@asu.lt

Algirdas RAILA, Institute of Energy and Biotechnology Engineering, Faculty of Agricultural Engineering, Aleksandras Stulginskis University, Studentu str. 15, LT-53362, Kaunas distr., Lithuania, e-mail: algirdas.raila@asu.lt

Vita TILVIKIENĖ, Institute of Agriculture, Lithuanian Research Center for Agriculture and Forestry, Instituto al. 1, LT-58344 Akademija, Kèdainiai distr., Lithuania; Institute of Energy and Biotechnology Engineering, Faculty of Agricultural Engineering, Aleksandras Stulginskis University, Studentų str. 15, LT-53362, Kaunas distr., Lithuania, e-mail: vita.tilvikiene@lammc.lt

Zofija JANKAUSKIENE், Institute of Agriculture, Lithuanian Research Center for Agriculture and Forestry, Instituto al. 1, LT-58344 Akademija, Kèdainiai distr., Lithuania, e-mail: soja@upyte.lzi.lt

Žydrè KADŽIULIENĖ, Institute of Agriculture, Lithuanian Research Center for Agriculture and Forestry, Instituto al. 1, LT-58344 Akademija, Kèdainiai distr., Lithuania, e-mail: zkadziul@1zi.lt

In the world, fossil fuel resources are constantly decreasing and increasing energy use. This leads to wider use of biomass in various industrial areas. Also, for the production of heat and electricity. Depending on the situation of current market, much attention is being paid to increasing the potential of biomass and to ensure the needs of users. Recently, much attention is paid to non-food energy plants, which could be used in thermochemical conversion technologies. These plants must be well adapted to climatic conditions, to grow a high biomass yield, to possess high energy value, easy to use for biofuel production and low environmental impact. Having a high energy potential and promising plants for cultivation in a changing climate conditions can be characterized and these plants: this is Miscantus spp. (namely miscanthus), Artemisia dubia Wall. (mugwort) and Cannabis sativa L. (fiber hemp).

The article summarizes long-standing biometric and thermal performance results on Miscantus spp. (namely miscanthus), Artemisia dubia Wall. (mugwort) and Cannabis sativa L. (fiber hemp). In Lithuania climate condition, it is possible to grow from 3.26 to 17.06 $\mathrm{t} \mathrm{ha}^{-1}$ of dry biomass per year from the mentioned plants. The calorific value of biomass has a huge influence on assessment of energy potential from plants. After combustion of 1 kilogram of Miscantus spp., Artemisia dubia Wall. and Cannabis sativa L. biomass it stands out on average $18.3 \pm 0.06,18.5 \pm 0.66$ and $17.43 \pm 0.06 \mathrm{MJ}$ of heat, respectively. An equally important property which assesses the suitability of biomass for biofuels is ash content. The average ash content of biomass from Miscantus spp. and Artemisia dubia Wall was $1.51 \pm 0.03 \%$ and $2.69 \pm 0.33 \%$, i.e. 2.22 times and 1.25 times lower than Cannabis sativa $\mathrm{L}$.

Keywords: Artemisia dubia Wall., assessment, biomass, Cannabis sativa L., coarse-energy plants, Miscantus spp.

\section{INTROCUCTION}

Many European Union countries, including Lithuania, are expanding the industry, continually rising energy volumes and the depletion of fossil fuel resources, are forcing to be interested in alternative energy usage possibilities. This increased demand for a forest biomass. In temperate countries, it has become a major renewable resource for heating and electricity production. According to Lithuanian Biomass Association data, biofuel use reached $64 \%$ of the heat supply sector in 2016 year (Biokuro panaudojimas...). It is planned that this quantity will seek $80 \%$ in 2020 year. However, wood is an important raw material in various sectors of economy. Improving the production of wood and processing technologies, it focuses on the saving biomass resources of forests, developing waste-free production. Also, they are looking for an alternative for wood - a new alternative energy plants, suitable for burning, electricity and production of heat. They must be undemanding to soil, for technological supply of growing and harvesting. They must have a high yield, good thermal properties and low environmental impact. Although now supply is dominated by the forest biomass, but also it expands on specially grown acreages of coarseenergy plants. Since 2008, the quantity of energy plant crops on average is increasing about a 319 ha per year.

Lately, much attention is given to coarse-energy plants, which are able to accumulate a large yield of dry matter. For example, switchgrass (Panicum virgatum L.) yields varies from 5 to $23 \mathrm{t} \mathrm{ha}^{-1} \mathrm{DM}$, raygras (Lolium ssp.) from 9 to 12 $\mathrm{t} \mathrm{ha}^{-1} \mathrm{DM}$, reed canary grass (Phalaris arundinacea) from 7 to $14 \mathrm{t} \mathrm{ha}^{-1} \mathrm{DM}$, cocksfoot grass (Dactylis glomerata L.) from 8 to $10 \mathrm{t} \mathrm{ha}^{-1} \mathrm{DM}$, namely miscanthus (Miscantus spp.) from 4 to $30 \mathrm{t} \mathrm{ha}^{-1} \mathrm{DM}$, common mugwort (Artemisia vulgaris) from 3.1 to $7.3 \mathrm{t} \mathrm{ha}^{-1}$ DM. (Heinsoo et al., 2011; Jasinskas et al, 2008; Šiaudinis et al., 2012; Kryževičienė et al., 2010).

Copyright (C) 2017 The Authors. Published by Aleksandras Stulginskis University. This is an open-access article distributed under the terms of the Creative Commons Attribution License (CC-BY 4.0), which permits unrestricted use, distribution, and reproduction in any medium, provided the original author and source are credited. 
In literature it emphasizes that the coarse-energy plants can grow for 10 or more years in the same place. This reduces costs of their production and has a positive influence on net energy balance. Thus, the coarse-energy plants can be a viable raw material for the production of solid biofuels.

Researchers specify three plants: Miscantus spp. (namely miscanthus), Artemisia dubia Wall. (mugwort) and Cannabis sativa L. (fiber hemp), which has a high-energy potential. It was determined that their yield varies from 3 to 35 $\mathrm{t} \mathrm{ha}^{-1} \mathrm{DM}$ in Lithuania (Kryževičienè et al., 2010; Slepetys at al., 2012; Tilvikiene at al., 2015; Titova, Bakšiene், 2015). It depends on the plant's growing year, fertilization, soil quality and other conditions. These plants are recommended for cultivation in an unused land areas. In Lithuania they account for about $20 \%$. In promoting broader their use for energy purposes, it is important to know these plants and to evaluate the thermal properties: calorific value, ash content, ash melting characteristics and so on. However, it is often neglected to take into account the growing and harvesting technologies. The complexity of harvest processing techniques and harvest time is no less important factors. This is also borne Prade et al. (2011), Volkavičiūtè et al. (2015), Komlajeva et al. (2012). Analyzing the coarse-energy plants is necessary to do their complex assessment covering both the technological characteristics and thermochemical properties.

The objective of research is to assess Miscantus spp. (namely miscanthus), Artemisia dubia Wall. (mugwort) and Cannabis sativa L. (fiber hemp) biometric and thermochemical conversion properties of their biomass.

\section{MATERIALS AND METHODS}

Miscantus spp. (namely miscanthus), Artemisia dubia Wall. (mugwort) and Cannabis sativa L. (fiber hemp) were grown in a plantation set up at an experimental basis of Lithuanian Research Centre for Agriculture and Forestry, and the research work on fuel preparation and thermal conversion was carried out at the Laboratory of Biomass Processes, Logistics and Solid Fuel Processing of the Faculty of Agricultural Engineering, Aleksandras Stulginskis University.

To evaluate yield a DM quantity was established in every sample of plant biomass after samples were dried for at $105^{\circ} \mathrm{C}$ temperature until a constant weight in drying cabinet using forced ventilation.

The assessment of biometric indicators from coarse-energy plants were carried out measurement length and diameters of the stem with meter and electric caliper "PROMA" (measured $50 \mathrm{~mm}$ from the bottom and from the top). Also each plant was weighed by the scales "SCALTEC SPO 51".

Calorific value was determined using the equipment IKA 2000 in accordance with the standard LST EN 14775 (2010). Ash content was determined using the CZYLOK equipment, in accordance with the standard LST EN 14918 (2010). The biomass energy potential was calculated according to the biomass yield per hectare and biomass heating value. All results obtained during the research were analyzed using MS Office Excel software (ANOVA).

\section{RESULTS AND DISCUSSION}

Lithuania is in the temperate climate zone, characterized by changeable weather. Frequent precipitation, changes in temperature has influence on coarse-energy plants cultivation, harvesting time and technical possibilities to cut harvest. The results of the experiment suggested that obtained biomass yield of Miscantus spp. and A. dubia Wall. was different from 2013 to 2016 year. It has an influence on different meteorological conditions at biomass cultivation time. The average biomass yield of Miscantus spp. was obtained 13.07 $\pm 0.56,9.83 \pm 2.09,16.0 \pm 0.67$ tons of dry matter per hectare in 2014,2015 and 2016 year respectively. At the same time, A. dubia - 1.21 and 1.39 times higher (in 2014 and 2015 year). In 2016 year, yield of A. dubia was obtained only $6.13 \pm 1.09 \mathrm{t} \mathrm{ha}^{-1} \mathrm{DM}$, but it has an influence on biomass from frostbite in April. The total biomass yield of Miscantus spp. and A. dubia is $35.64^{1}$ and $38.9 \mathrm{t} \mathrm{ha}^{-1}$ respectively within 3 years. In the reference it indicates that biomass yield of perennial willow is up to $44.6 \mathrm{t} \mathrm{ha}^{-1} \mathrm{DM}$ in a three-year growing-harvesting cycle, i.e. the average of $14.9 \mathrm{t} \mathrm{ha}^{-1}$ DM per year (DEFRA... 2007). Meanwhile, yield of A. dubia varies from 3 to $35 \mathrm{t} \mathrm{ha}^{-1}$ DM per year in Lithuanian natural conditions (Kryževičienè et al., 2010; Slepetys at al., 2012; Tilvikiene at al., 2015; Titova, Bakšienė, 2015), while yields of Miscantus spp. varies from 13 to $48 \mathrm{t} \mathrm{ha}^{-1}$ DM in the world (Angelini et al., 2009; Kołodziej et al., 2016).

The average biomass yield of Cannabis sativa L. is $10.91 \pm 1.00 \mathrm{t} \mathrm{ha}^{-1} \mathrm{DM}$, i.e. it varies from 9.27 (Fedora 17) to $13.31 \mathrm{t} \mathrm{ha}^{-1} \mathrm{DM}$ (Wojko), depending on variety of Cannabis sativa $\mathrm{L}$. In the countries with temperate climatic conditions, the average yield of these coarse-energy plants is about $20 \mathrm{t} \mathrm{ha}^{-1} \mathrm{DM}$, i.e. 1.83 times higher than the Lithuanian conditions (Struik et al., 2000; Cappelletto at al, 2001). However, Pradeet al. (2011) reported that Cannabis sativa L., whereas biomass yield varied between 10 and $14.5 \mathrm{t} \mathrm{ha}^{-1} \mathrm{DM}$ in Sweden.

Environmental conditions have an influence on variation of humidity in coarse-energy plants and other properties. Variation of moisture content (minimum and maximum values) of biomass in harvesting time presented in Figure 1. Biomass of Cannabis sativa L. is harvested after the end of their flowering and when the first matured seed appeared (Komlajeva et al., 2012; Jankauskienè, Gruzdevienè, 2015), i.e. end of September - beginning of October. However, yield of Cannabis sativa L. can be harvested by the end of October, according to the meteorological conditions during the growing season of plants. At that time, the average moisture content of biomass is $62.75 \pm 3.51 \%$. However, this moisture content of biomass complicates their storage after harvesting: when this moisture content of biomass is in storage their layers creates favorable conditions for biochemical and microbiological processes (Tilvikiene et al., 2015; Ambrulevičius, 2010). Therefore diminishing the quality of biomass and is

\footnotetext{
${ }^{1}$ The yield was assessed only $6.13 \mathrm{t} \mathrm{ha}^{-1} \mathrm{DM}$ in 2016.
} 
increasing their wastage. In many cases, to devote a long-term storage of biomass for coarse-energy plants humidity should not exceed $20 \%$ (Tilvikiene et al., 2015; Ambrulevičius, 2010). In such moisture content of biomass without additional energy input we can use for energy purposes. Biomass can be dried to $20 \%$ moisture content by natural environmental conditions, when it is left to early spring, i.e. till March. It can be dried under investigation biomass of Miscantus spp. and A. dubia. The average moisture content of biomass from coarse-energy plants was $14.28 \pm 2.42 \%$ in March, i.e. from September to March, under natural environmental conditions, the average moisture content of biomass can be reduced by 4.4 times $(48.47 \%)$. However, if the harvesting time of coarse-energy plants is postponed until April, then there must be assessment and the opportunity to enter the field. The rising environmental temperature has influence on access to plantations and new crops germination. Also, rains started in spring increases a still moisture content of uncut biomass average up to 1.68 times, i.e. $9.74 \%$.

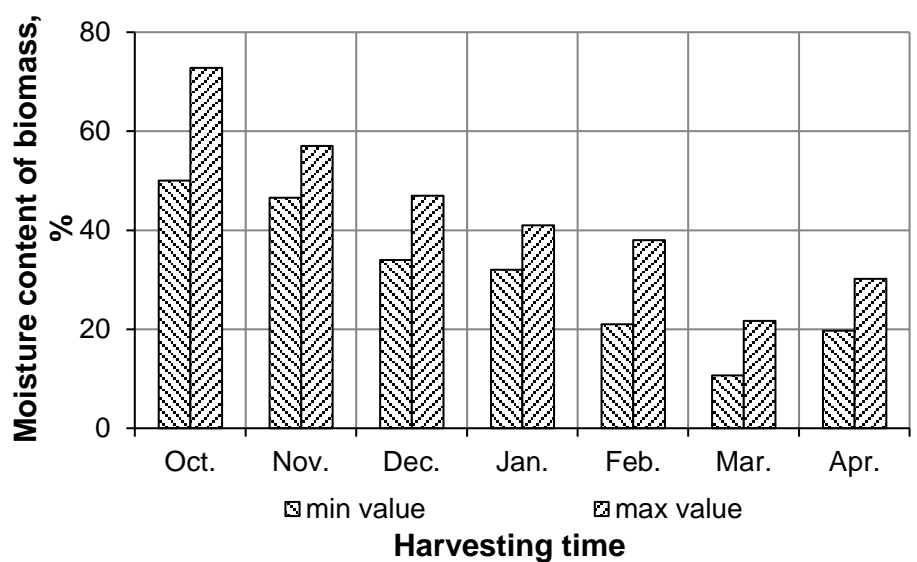

Figure 1. Variation of moisture content of biomass in harvesting time

Biometric indicators of coarse-energy plants presented in Table 1. Analyzing the perennial coarse-energy plants (Miscantus spp. and A. dubia), the average heights of their biomass were $2.36 \pm 0.14 \mathrm{~m}$ and $2.41 \pm 0.17 \mathrm{~m}$, respectively. I.e. 1.38 times and 1.41 times lower than the average $(3.34 \pm 0.14 \mathrm{~m})$ of Cannabis sativa L. Also, the average stems of Miscantus spp. weighed 1.06 times less, and stems of $A$. dubia -1.02 times more than Cannabis sativa L. (66.86 \pm 14.27 g). Perennial coarse-energy plants characterized as smaller plants than the annual Cannabis sativa L.

Table 1. Biometric indicators of coarse-energy plants

\begin{tabular}{|c|c|c|c|c|c|}
\hline \multirow{2}{*}{\multicolumn{2}{|c|}{ Plants }} & \multirow[b]{2}{*}{ Height, m } & \multirow[b]{2}{*}{ Weight of stem, $g$} & \multicolumn{2}{|c|}{ Thickness of stem, mm } \\
\hline & & & & $\begin{array}{c}50 \mathrm{~mm} \text { from the } \\
\text { bottom }\end{array}$ & $\begin{array}{c}50 \mathrm{~mm} \text { from the } \\
\text { top }\end{array}$ \\
\hline \multicolumn{2}{|c|}{ Miscantus spp. } & $2.36 \pm 0.14$ & $62.92 \pm 9.16$ & $8.84 \pm 0.39$ & $5.90 \pm 0.59$ \\
\hline \multicolumn{2}{|c|}{ Artemisia dubia Wall. } & $2.41 \pm 0.17$ & $68.46 \pm 13.39$ & $9.09 \pm 0.65$ & $1.38 \pm 0.40$ \\
\hline \multirow{9}{*}{$\begin{array}{l}\text { Cannabis } \\
\text { sativa } \mathrm{L} .\end{array}$} & Beniko $^{2}$ & $3.16 \pm 0.49$ & $102.22 \pm 62.65$ & $16.01 \pm 4.98$ & $2.69 \pm 1.90$ \\
\hline & Bialobrzeskie $^{2}$ & $3.42 \pm 0.15$ & $69.82 \pm 31.52$ & $13.03 \pm 2.76$ & $3.02 \pm 0.59$ \\
\hline & Epsilon $68^{2}$ & $3.43 \pm 0.24$ & $60.49 \pm 23.98$ & $12.33 \pm 2.29$ & $2.08 \pm 1.63$ \\
\hline & Fedora $17^{2}$ & $3.26 \pm 0.24$ & $54.80 \pm 32.36$ & $12.13 \pm 3.89$ & $1.44 \pm 0.44$ \\
\hline & Felina $32^{2}$ & $3.45 \pm 0.20$ & $87.80 \pm 29.19$ & $14.09 \pm 2.25$ & $3.00 \pm 1.45$ \\
\hline & Futura $75^{2}$ & $3.56 \pm 0.20$ & $67.80 \pm 29.59$ & $13.90 \pm 1.79$ & $2.43 \pm 1.35$ \\
\hline & Santhica $27^{2}$ & $3.49 \pm 0.21$ & $66.80 \pm 26.61$ & $12.33 \pm 2.03$ & $1.42 \pm 0.36$ \\
\hline & USO $31^{2}$ & $2.96 \pm 0.26$ & $46.64 \pm 21.87$ & $11.76 \pm 2.75$ & $3.29 \pm 1.15$ \\
\hline & Wojko $^{2}$ & $3.30 \pm 0.25$ & $45.34 \pm 29.18$ & $10.69 \pm 3.55$ & $2.13 \pm 0.87$ \\
\hline
\end{tabular}

While analyzing the calorific value of biomass from coarse-energy plants it was found out that calorific value of perennial plants (Miscantus spp. and A. dubia) (respectively $18.29 \pm 0.06 \mathrm{MJ} \mathrm{kg}^{-1}$ and $18.50 \pm 0.66 \mathrm{MJ} \mathrm{kg}^{-1}$ ) were 1.02 and 1.03 times higher than the average calorific value of Cannabis sativa L. (17.92 $\pm 0.24 \mathrm{MJ} \mathrm{kg}^{-1}$ ) (Fig. 2). However, the highest calorific value of annual plants $\left(18.52 \pm 0.14 \mathrm{MJ} \mathrm{kg}^{-1}\right)$ determined variety of Bialobrzeskie, divorced a similar quantity of heat as the biomass of perennial plants. The lowest calorific value was described as a variety of Felina 32 (17.53 $\pm 0.12 \mathrm{MJ} \mathrm{kg}^{-1}$ ), i.e. 1.04 and 1.06 times less than the Miscantus spp. and A. dubia. While analyzing the data scientists presented the results of calorific value of biomass from perennial willow (from 18.6 to $19.0 \mathrm{MJ} \mathrm{kg}^{-1}$ ) (Eisenbies at al., 2016) and compared with investigated plants it was found that calorific value of all plants was lower than willow.

\footnotetext{
${ }^{2}$ Different variety of Cannabis sativa $\mathrm{L}$.
} 


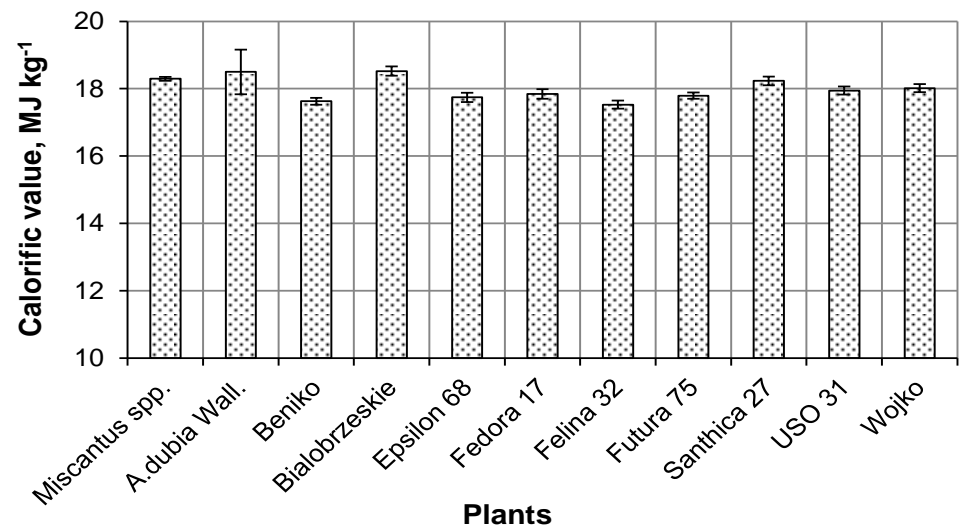

Figure 2. Calorific value of biomass from coarse-energy plants

The average ash content of biomass from Miscantus spp. and A. dubia was $1.51 \pm 0.03 \%$ and $2.69 \pm 0.33 \%$, i.e. 2.22 times and 1.25 times lower than Cannabis sativa L. (3.36 $\pm 0.23 \%$ ) (Fig. 3). Although the lowest ash content $(2.90 \pm 0.04 \%)$ was characterized a variety of Fedora 17, but their ash content was 1.92 times and 1.08 times higher than the Miscantus spp. and A. dubia. The highest (3.90 $0.08 \%)$ ash content was characterized as a variety of Beniko, i.e. 2.58 times and 1.45 times more than the Miscantus spp. and A. dubia. Analyzing ash content of coarse-energy plants was in willow within the range (from 1.2 to $4.9 \%$ ) (Ambrulevičius, 2010; Eisenbies et al., 2016).

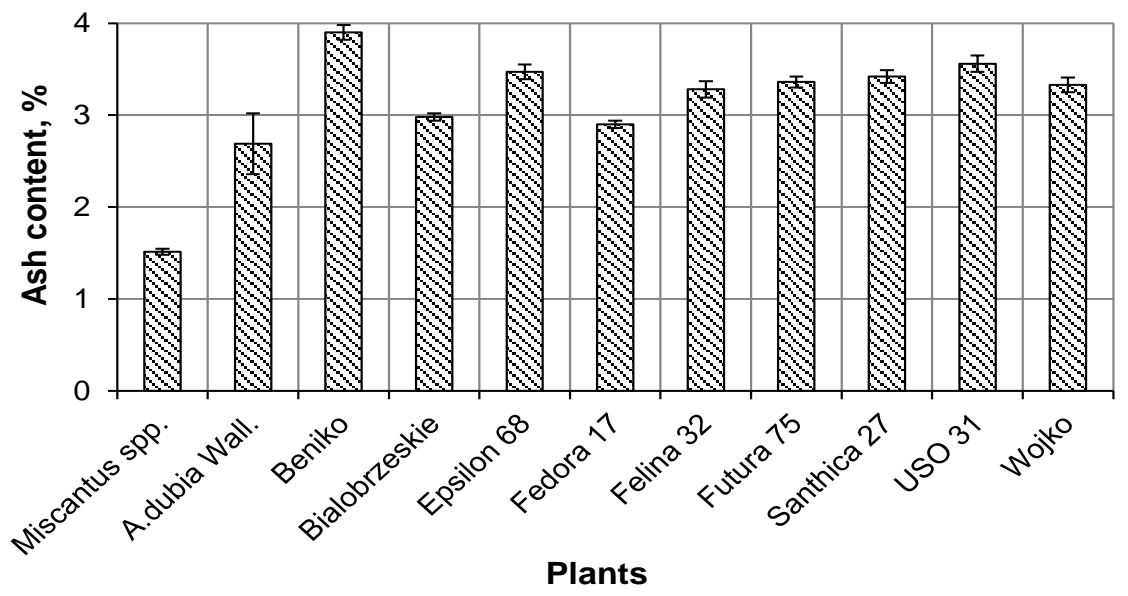

Figure 3. Ash content of biomass from coarse-energy plants

Within three growing years (2014-2016), heat content of biomass from coarse-energy plants (Miscantus spp. and A. dubia) was obtained 711.64 and $659.33 \mathrm{GJ} \mathrm{ha}^{-1}$ thermochemical conversion during (Fig. 4). The heat content of $A$. dubia was obtained only $113.40 \mathrm{GJ} \mathrm{ha}^{-1}$ in 2016, it has an influence on formed frosts and losses of biomass yield. The average heat content was obtained from $219.78^{3}$ (A. dubia) to 237.21 (Miscantus spp.) GJ ha-1 .

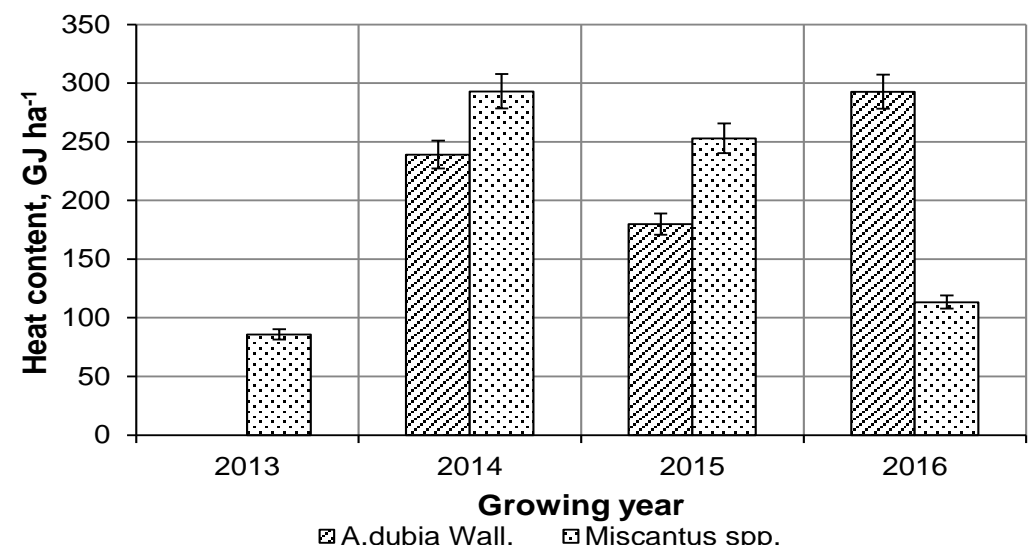

Figure 4. The average heat content of biomass from coarse-energy plants (Miscantus spp. and A. dubia) obtained thermochemical conversion during ${ }^{4}$

\footnotetext{
${ }^{3}$ In calculating the average quantity of heat was evaluated $113.40 \mathrm{GJ} \mathrm{ha}^{-1}$ a thermochemical conversion during in 2016 years.

${ }^{4}$ Yield of Miscantus spp. hasn't been evaluated the first growing (2013) year.
} 
The average heat content of biomass obtained from the annual Cannabis sativa L. was $195.51 \pm 18.69$ GJ ha ${ }^{-1}$ thermochemical conversion during, i.e. 1.21 and 1.12 times less than Miscantus spp. and A. dubia (Fig. 5). The highest (239.85 $\left.\pm 11.99 \mathrm{GJ} \mathrm{ha}^{-1}\right)$ quantity of heat was obtained from variety of Wojko thermochemical conversion during, the lowest (165.47 $\left.\pm 8.86 \mathrm{GJ} \mathrm{ha}^{-1}\right)$ - Fedora 17 , i.e. 1.25 times lower compared with variety of Wojko.

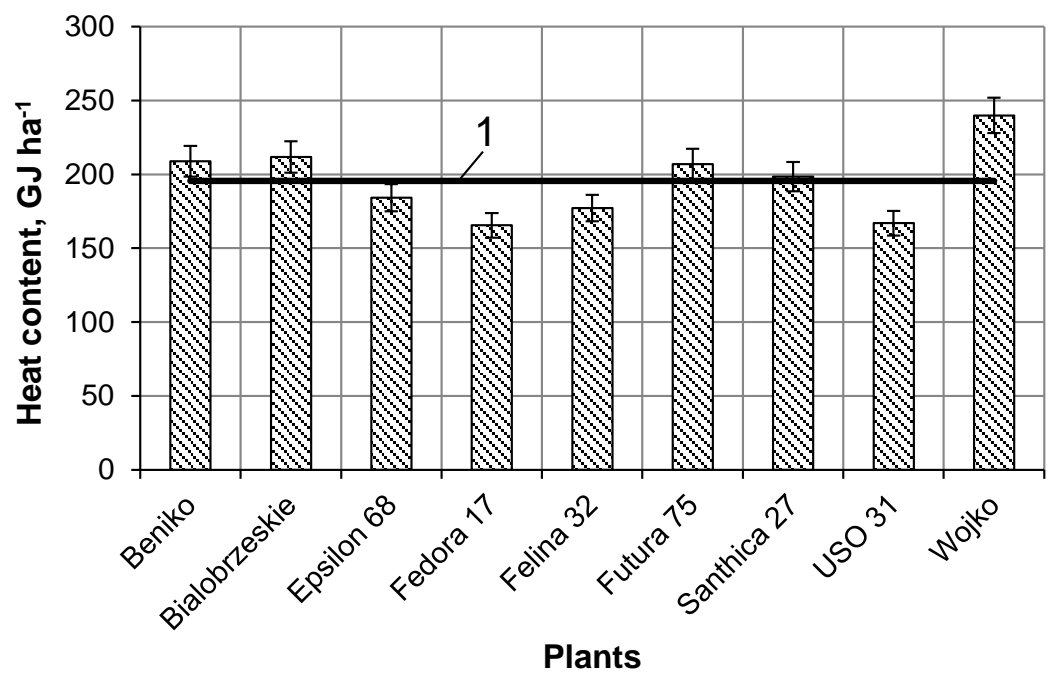

Figure 5. The average heat content of biomass from coarse-energy plants (Cannabis sativa L.) obtained thermochemical conversion during: 1 - the average value

\section{CONCLUSIONS}

1. The average biomass yield of Miscantus spp. was obtained $13.07 \pm 0.56,9.83 \pm 2.09,16.0 \pm 0.67$ tons of dry matter per hectare in 2014, 2015 and 2016 year respectively. At the same time, A. dubia - 1.21 and 1.39 times higher (in 2014 and 2015 year). In 2016 year, yield of $A$. dubia was obtained only $6.13 \pm 1.09 \mathrm{t} \mathrm{ha}^{-1} \mathrm{DM}$, but it has an influence on biomass from frostbite in April. The average biomass yield of Cannabis sativa L. is $10.91 \pm 1.00 \mathrm{t} \mathrm{ha}^{-1} \mathrm{DM}_{\text {, i.e. it }}$ varies from 9.27 (Fedora 17) to $13.31 \mathrm{t} \mathrm{ha}^{-1} \mathrm{DM}$ (Wojko), depending on variety of Cannabis sativa $\mathrm{L}$.

2. Analyzing the perennial coarse-energy plants (Miscantus spp. and A. dubia), the average heights of their were 1.38 times and 1.41 times lower than the average $(3.34 \pm 0.14 \mathrm{~m})$ of Cannabis sativa $\mathrm{L}$.

3. It was found out that calorific value of perennial plants (Miscantus spp. and A. dubia) were 1.02 and 1.03 times higher than the average calorific value of Cannabis sativa L. (17.92 $\left.\pm 0.24 \mathrm{MJ} \mathrm{kg}^{-1}\right)$.

4. The average ash content of biomass from Miscantus spp. and A. dubia was $1.51 \pm 0.03 \%$ and 2.69 $\pm 0.33 \%$, i.e. 2.22 times and 1.25 times lower than Cannabis sativa L.

5. The average heat content of biomass obtained from the annual Cannabis sativa L. was $195.51 \pm 18.69 \mathrm{GJ}^{-1}$ thermochemical conversion during, i.e. 1.21 and 1.12 times less than Miscantus spp. and A. dubia.

\section{REFERENCES}

1. Ambrulevičius, R. 2010. Biomasès deginimas mažos bei vidutinès galios katilinèse ir emisijų problemos (Burning of biomass in small and average boiler-houses and emission problems). Energetika, Vol. 56(2), pp. 103-109. [In Lithuanian].

2. Angelini, L.G., Ceccarini, L., Nassi, O., Di Nasso, N., Bonari, E. 2009. Comparison of Arundo donax L. and Miscanthus x giganteus in a long-term field experiment in Central Italy: Analysis of productive characteristics and energy balance. Biomass and Bioenergy, Vol. 33, pp. 635-643. https://doi.org/10.1016/j.biombioe.2008.10.005

3. Biokuro panaudojimas Lietuvos šilumos tiekimo sektoriuje (Use of biofuels in the Lithuanian heat supply sector). Available at: http://www.biokuras.lt/. [In Lithuanian]

4. Cappelletto, P, et al. 2001. Italy-grown hemp: yield, composition and cannabinoid content. Industrial Crops and Products, Vol. 13, pp. 101-113. https://doi.org/10.1016/S0926-6690(00)00057-1

5. DEFRA. 2007. Assessing Biomass Miscanthus and Short Rotation Coppice Willow and Poplar Varieties: The Way Forward. Final Report Project NF0435.

6. Eisenbies, M.H., Volk, T.A., Patel, A. 2016. Changes in feedstock quality in willow chip piles created in winter from a commercial scale harvest. Biomass and Bioenergy, Vol. 86, pp. 180-190.https://doi.org/10.1016/j.biombioe.2016.02.004

7. European Standards. LST EN 14775: Solid biofuels. Determination of ash content, 2010.

8. European Standards. LST EN 14918: Solid biofuels. Determination of calorific value, 2010.

9. Heinsoo, K., Hein, K., Melts, I., Holm, B., Ivask, M. 2011. Reed canary grass yield and fuel quality in Estonian farmers' fields. Biomass and Bioenergy, Vol. 35, pp. 617-625. https://doi.org/10.1016/j.biombioe.2010.10.022

10. Jankauskienè, Z., Gruzdevienè, E. 2015. Screening of Industrial Hemp (Cannabis sativa L.) Cultivars for Biomass Yielding Capacities in Lithuania. Journal of Natural Fibers, Vol. 12(4), pp. 368-377. https://doi.org/10.1080/15440478.2014.929556 
11. Jasinskas, A., Zaltauskas, A., Kryzeviciene, A. 2008. The investigation of growing and using of tall perennial grasses as energy crops. Biomass and Bioenergy, Vol. 32, pp. 981-987. https://doi.org/10.1016/j.biombioe.2008.01.025

12. Kołodziej, B., Antonkiewicz, J., Sugier, D. 2016. Miscanthus $\times$ giganteus as a biomass feedstock grown on municipal sewage sludge. Industrial Crops and Products, Vol. 81, pp. 72-82. https://doi.org/10.1016/j.indcrop.2015.11.052

13. Komlajeva, L.., Adamovičs, A., Poiša, L. 2012. Comparison of diferrent energy crops for solid fuel production in Latvia. Renewable Energy and Energy Efficiency, pp. 45-50.

14. Kryževičienè, A., Šarūnaitè, L., Stukonis, V., Dabkevičius, Z., Kadžiulienė, Ž. 2010. Daugiamečiu kiečiu (Artemisia vulgaris L. ir Artemisia dubia Wall.) potencialo biokuro gamybai ịvertinimas (Assessment of perennial mugwort (Artemisia vulgaris L. and Artemisia dubia Wall.) potential for biofuel production). Agricultural Sciences, Vol. 17(1-2), pp. 32-40. [In Lithuanian].

15. Struik, P.C., Amaducci, S., Bullard, J.M., Stutterheim, N.C., Venturi, G., Cromack, K.T.H. 2000. Agronomy of fibre hemp (Cannabis sativa L.) in Europe. Industrial Crops and Products, Vol. 11, pp. 107-18. https://doi.org/10.1016/S0926$\underline{6690(99) 00048-5}$

16. Prade, T., Svensson, S.E., Andersson, A., Mattsson, J.E. 2011. Biomass and energy yield of industrial hemp grown for biogas and solid fuel. Biomass and Bioenergy, Vol. 35, pp. 3040-3049. https://doi.org/10.1016/j.biombioe.2011.04.006

17. Slepetys J., Kadziuliene Z., Sarunaite L., Tilvikiene V., Kryzeviciene A. 2012. Biomass potential of plants grown for bioenergy production. Int. Sci. Conf. Renew. Energy Energy Effic., pp. 66-72.

18. Šiaudinis G., Jasinskas A., Šlepetienė A., Karčauskienė D. 2012. The evaluation of biomass and energy productivity of common mugwort (Artemisia vulgaris L.) and cup plant (Silphium perfoliatum L.) in Albeluvisol. Žemdirbysté=Agriculture, Vol. 99(4), pp. 357-362.

19. Tilvikiene V., Kadziuliene Z., Raila A., Zvicevicius E., Liaudanskiene I., Volkaviciute Z., Pociene L. 2015. 23rd European Biomass Conference and Exhibition, pp. 1-4, 1-4 June 2015, Vienna, Austria.

20. Titova J., Bakšienè E. 2015. Nuotekų dumblo komposto ịtaka energetinių augalų - pavėsinio kiečio (Artemisia dubia Wall.) ir sidos (Sida hermaphrodita (L.) Rusby) - augimui (The influence of sewage sludge compost on the growth of energy plants mugwort (Artemisia dubia Wall.) and virginia fanpetals (Sida hermaphrodita (L.) Rusby). Žemés ükio mokslai, Vol. 22(3), pp. 155-162. [In Lithuanian].

21. Volkaviciute Z., Raila A., Kadziuliene Z., Zvicevicius E., Tilvikiene V., Tauras E. 2015. Drying Research In Perennial Mugwort (Artemisia Dubia Wall.). Engineering for rural development : 14th international scientific conference : proceedings, pp. 168-173.,May 20-22. Jelgava. 